\title{
Conceptual Scheme of Digital Transformation of Business Model of Industrial Enterprises
}

\author{
Volodymyr Bodrov, Larisa Lazebnyk, Viktoriya Hurochkina, Ruslana Lisova
}

\begin{abstract}
Article describes features of digital transformations that affect global economy as a whole and national economy of Ukraine, changing business models of industrial enterprises and quality of life societies. Stages of transition Ukrainian society, business and state institutions to digital technologies have been determined. Selected Agenda and Concept of Digital Economy as the main directions in way of digitalization national economy of Ukraine. It is stated that digital transformation influences business models and national economy by initiating synergistic and emergent effects. Stages of integration innovative technologies and their influence on development country are outlined. Central to digital transformation is process of automation in lives of everyone, society, businesses, organizations, government organizations and government agencies. Key elements of conceptual scheme of digital transformation business model of industrial enterprises, which allow focusing on social and industrial block, which gives opportunity to adapt the activity of industrial enterprises as effectively as possible and provides flexibility of response management decisions in transformation environment. Predicted results of digital transformation of the country and industrial enterprises are highlighted.
\end{abstract}

Keywords: business model, conceptual scheme, digital transformations, technological innovations.

\section{INTRODUCTION}

Digital transformation as global trend of the world economy offer unique opportunities for development of industrial enterprises and improve quality of Ukrainian life in General. Gradually increases transition of Ukrainian companies, enterprises and government institutions on digital technologies, becoming a key agenda on the way to prosperity and welfare of the country. Digital transformation affects business models and economy of each country of the world, initiating the synergistic and emergent effects.

Central to digital transformation is the process of automation, not only enterprises, organizations, state institutions and governmental organizations, but also to society and individual (due to the work of human body).

According to the study by McKinsey Global Institute potential impacts of digitalization and its influence on national economy of the United States determined that the

Revised Version Manuscript Received on October 15, 2019.

Volodymyr Bodrov, Department of Enterprise Economics, University of the State Fiscal Service of Ukraine, Irpin, Ukraine. Email: vgbodrov@gmail.com

Larisa Lazebnyk, Department of Enterprise Economics, University of the State Fiscal Service of Ukraine, Irpin, Ukraine. Email: 111808816@gmail.com.

Viktoriya Hurochkina*, Department of Enterprise Economics, University of the State Fiscal Service of Ukraine, Irpin, Ukraine. Email: viktoriav2005@ukr.net

Ruslana Lisova, Department of Enterprise Economics, University of the State Fiscal Service of Ukraine, Irpin, Ukraine. Email: m-ruslana@ukr.net part jobs has declined, and in return projected net positive increase in the number of jobs in long term till 2030 [1]. experts of McKinsey Global Institute noted that "automation does not occur in a vacuum", so driver in this process just is the society. During transformation processes is important specific as "ability to adapt and thrive in an environment of change" this is what we can expect today and in near future[2].

Ukraine is no exception to the global trend. Industry 4.0 for innovative and digital technology En masse was carried out as at state level in development programs of country and corporate levels that affect the strategic directions and business ideas. A response to trans formative change of the economy and society actualization research directions practical challenges of digitalization and its influence on the level of development of industrial enterprises.

In our study, we prove key elements of digital transformation of business models for industrial enterprises, and built a conceptual framework of formation of innovative business processes and transformation with purpose of making effective management decision.

\section{LITERATURE REVIEW}

Issues of impact digitization and digital technologies on company's activity and their business models have been considered by domestic and foreign scientists.

The work A. Burdina,, T. Nikolenko, L. Semina [3] studied development of digital economy as catalyst, which is capable to provide conditions and infrastructure for operation of high-tech enterprises. Authors of "Role of Digital Economy in Creating Innovative Environment" have developed a calculation mechanism to determine effectiveness of investment programs. They carried out testing methodologies for adjustments expert assessments when analyzing efficiency projects in digital economy.

Arun Kumar Singh and Thirumoorthi in "The Impact of Digital Disruption Technologies on Customer Preferences: Case of Retail Commerce" [4] emphasize that digitization processes have caused a huge shift in consumer behavior, technologies are identified as a powerful tool for influencing and changing customer preferences behavior. Authors note that client orientation is a decisive factor of enterprises survival. 
Use of artificial intelligence as driving force of the 4th Industrial Revolution was explored in Seong-Hoon Lee and Hyun-Soo Jin [5]. In this work key technological trends related to self-control, which is a visual representation of two types intelligent machines and technologies that operate through voice recognition.

Investigation of introduction advanced technologies in production takes place in different directions. For example, $\mathrm{P}$. Perumal, S. Hammam, and C.Tay in "Performance Measure of Industrial Robotics In Lean Enterprise: A Case Study in Semiconductor Industry" [6] studied implementation of industrial robotics. Authors proposed a performance measurement method using QCDAC, and made a classification according to principles of lean production, they spent identifying and ranking the performance using methodology of interpretative structural modeling (ISM). The result of ISM study demonstrates those performance indicators that have a critical impact on industrial robotics to support lean production.

A. Wardaya, Sasmoko et.al [7] described impact of digital technology on SME performance in Indonesia. Research shows almost hypothesis that connects enterprise orientation (EO), possibilities of digital technology (DT) and productivity of SMEs (SP). Paper shows that DT acts as a mediator in relationship between EO and SP.

In today's economic environment, role of advanced technologies in production increasing rapidly. In this context, it is urgent research M. Sangeetha, S.Arulselvi, et.al. [8] within which scientists have analyzed feasibility of using the Internet of Things in manufacturing. They proposed to introduce a network of automatic track production programs. Paper "IOT Based Industrial Automation" selected key technologies and applications, based on using of IOT, shown the problems that arise in implementing of these technologies in production.

Goal of digital transformation is to grow productive forces, and within Digital Industry 4.0, digital production is a key aspect. In research E. Istomina [9] disclosed relevant questions of estimation trends digitalization. Author examines methods of evaluating digitalization at macro level and individual business entity.

Purpose scientific work "Guiding manufacturing companies towards digitalization a methodology for supporting manufacturing companies in defining their digitalization roadmap" A. Carolis, M. Macchi,, et.al [10] is to define a roadmap digital transformation of enterprises. To this end, developed and used model of maturity DREAMY ((Digital Readiness Assessment Maturity model). Model allows us to estimate current number willingness of manufacturing companies to embedded technologies and organizational processes.

Based on approaches to digital transformation and existing theories of business model innovation, D. Shalmo, C. Williams, L. Boardman, in their scientific work "Digital transformation of bussines models - best practice, enablers and roadmap" [11] developed a sequence of digital transformation business models and categories are tools used in process of digital transformation, each phase.

Separate interest in work «Estimation of Innovative Business Processes of Enterprises in Conditions of Emergence Economic» which comprehensively examines the impact of innovative business processes on development of industrial enterprises [12].

Even processes of digitization are integrated into scientific sphere of Ukrainian community [13].

Despite the work done by digital technology researchers on their impact on labor productivity and development of business organization models that underpin current management systems of modern industrial enterprises, their results are not yet capable of delivering a breakthrough in operational efficiency. Methodological study of possibility transferring is successful experience in use of digital technologies for enterprises in different sectors of economy requires additional scientific and practical efforts. Developing a comprehensive conceptual scheme for digital transformation of a business model industrial enterprises acceptable for implementation in practice is even more complex. In these circumstances, development of scientifically sound and practically significant recommendations in field of methodological support for digital transformation business model of industrial enterprises will positively affect activity of participants in industrial market and economy as a whole.

\section{METHODOLOGY AND RESERCH DESICN}

For basis of construction of conceptual chart of digital transformation of business model of industrial enterprises empiric proofs and general lines between the results of activity, collected during monitoring of official figures Ukrainian companies and applied researches, were taken in the real article. This analysis was conducted by questioning at level TOP managers during the one-day visit of the Ukrainian companies.

\section{PREREQUISITES OF FORMATION}

Development of digital transformation of Ukraine economy and business models is receiving much attention today from government and scientific world. According to a rating of International Telecommunication Union (ITU), level of ICT Development Index Ukraine is ranked only at 79 positions, when in 2013 level of Ukraine was at 68 positions. Therefore, given declining dynamics of Ukraine's ICT rating, government has made a decision on "digital transformation". In December 2016, Ministry of Economic Development and Trade of Ukraine presented the Digital Agenda of Ukraine 2020 project [15], which became fundamental model for shaping policy areas, priority areas and initiatives, and project of "digitization" of Ukraine for the next 3 years. Project defines basic principles of development digital environment for development digital economy of Ukraine. Directions of implementation initiatives on transformation of state organizations through "digitalization" by basic strategic technologies are defined. Today there are more than 1000 IT enterprises in Ukraine, employing over 100,000 IT professionals: developers, testers, product managers and others.

The second step was adoption of Digital Economy and 
Society Development Concept for 2018-2020, which was approved by Decree Cabinet of Ministers of Ukraine in January 17, 2018, No. 67-p, under digitization of society and state, "saturation of physical world with electronic-digital devices, means, systems and establishment of electronic-communication exchange between them, which in fact makes it possible to integrate virtual and physical, that is, to create cyber-physical space. Digitalization is a recognized mechanism of economic growth due to ability of technologies to positively influence the efficiency, effectiveness, value and quality of economic, social and personal activity "[16].

Influenced by development of information technology, productivity is rapidly increasing, while intellectual capabilities that are reflected in related products are expanding. This is all being generated in a new era of IT competition. Technologies are changing not only the value chain of products and services, but also strategic decisions of participants production and innovative business processes. The result is synergy and / or emergent properties of economic system.

Evolutionary transformations of digital and physical worlds take the following form:

Cyber-physical systems (CFS) allow you to combine computing and physical (mechanical or electronic) capabilities. CFSs allow for information sharing, monitoring, control, optimization and autonomy. For example, an autonomous automated intelligent production line with production processes. Such CFS is always connected to individuals through the Internet.

Cyber-human systems (CHS) are integrated information technologies into human organisms. For example, health sensors or innovative computer displays and tactile interfaces designed for visually impaired.

Digital transformation is affecting business model and behavior of businesses. As business owners, resellers, and customers become informed, their decisions, ratings, and purchases change. There is competition for end-user interface, which is largely independent of where the company is in digital transformation chain. Transition to "digital" influences established relationships with clients, as well as all innovative business processes, focusing on the needs of client.

Digital transformation of business model industrial enterprises can occur at the level of individual units value chain, and can dramatically change business. Intelligent, smart and innovative connected products are expanding. This emergent generation is known as Internet of Things and ushers in a new era of competition. Ordinary competitive environment is transformed by influence of changing nature "things", which also transforms competitive transformations.

After transformation of competitive environment comes stage transformation of technological infrastructure, called "Technology stack" and has a multilevel structure. For example, it may contain modified technology, software applications and operating systems, network communications, clouds, bots, and more.

Building on the conceptual scheme for digital transformation of a business model of industrial enterprises is a sequence of steps developed by German economists D. Schallmo, CA Williams \& L. Boardman in 2017 and refined by elements of cross section social and industrial block and these key tools of system, which gives ability to adapt activities of industrial enterprises as efficiently as possible and provides flexibility to respond to management decisions in a transformational environment.

\section{CONCEPTUAL DIAGRAM OF DIGITAL TRANSFORMATION OF BUSINESS MODEL OF INDUSTRIAL ENTERPRISES}

Will consider the sequence of stages becoming digital transformations in Country and forming conceptual chart of digital transformation business model of industrial enterprises, key changes and instruments of realization more detailed (Fig. 1).

Ukraine and digitalization its national economy are at stage of implementation technology in public sector of administrative services and partial use of innovative technologies by society, and in small amount this is reflected in medical and business sectors. Use of digital technology in business models in industrial enterprises is only just beginning, so let's look at theoretical aspect of study that chosen.

Digitalization, as a global trend in global economy, has a large number of interpretations and affects all sectors of national economy and economic activity of digital economy entities. The main drivers of global transformation challenges are presence in economic system of innovative technologies and business processes that have characteristics of applied tools, such as: Networking, Digital Data, Digital Customer Access, Automation.

Key tools for digital transformation of national economy are a set of specific activities and services, such as Digital Data. It is creation of certain database of digitized data to facilitate their processing and analysis, aimed at simplifying procedures for forecasting and making managerial strategic decisions. In context of transformational change, Automation combines classic technology and artificial intelligence. This combination allows system to operate autonomously and self-organized. The positive effects are the reduction of errors and the intensification of business processes with reduced operating costs. Tools such as Digital Customer Access provide direct access to the customer through the mobile Internet.

This simplifies the process and enhances transparency and service delivery. Mobile and wired value chain networking allows you to enhance communication and synchronize the work of distribution chains. Positive features of networking digitalization are intensification of working capital turnover, reduction of production time and innovation cycles. However, list of tools for digitization of economy is constantly expanding, as economic system is characterized by synergistic and emergent characteristics.

One example of digital transformation is Airbus, which has developed bionic components of A350 aircraft - bionic brackets that have been successfully tested. Made bracket was on a $3 \mathrm{D}$ printer made of titanium powder. This composition of work piece makes it possible to enhance

and $E_{n}$ IJRTE Published By: 


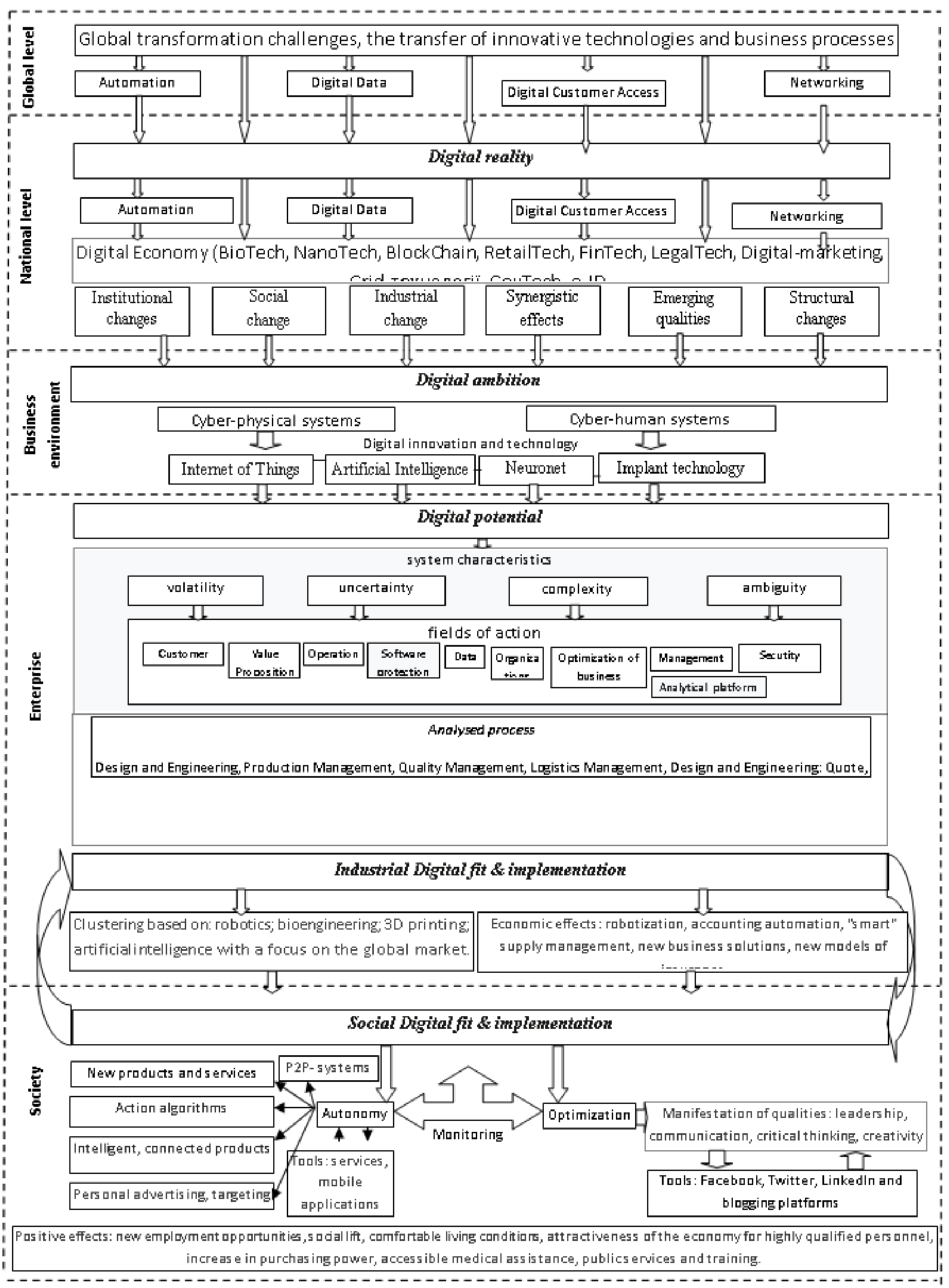

Fig.1 Conceptual scheme of digital transformation of business model of industrial enterprises 
strength function. Advantages of using digital technology in manufacture of aircraft brackets include: reducing fuel consumption, reducing material consumption and weight $(30 \%)$; production mobility (on site).

At national level, innovative applied technologies create Digital Reality, characterized by institutional, social, industrial changes in society and state, creating a "new" economy with digital characteristics. In our opinion, key tools of Digital Economy are BioTech, NanoTech, BlockChain, RetailTech, FinTech, LegalTech, Digital Marketing, Grid Technologies, GovTech, e-ID. Introduction of such technologies in country changes the understanding of digital reality not only of government but society as a whole.

With effective implementation and implementation of Digital Reality tools in national economy, Digital Ambition manifests itself in business environment.

This is the next stage of digital transformation that industrial enterprises are adapting to thanks to a supportive business environment. The level of favor ability determines readiness of business structures to change and their flexibility.

Digital Ambition sets pace and sets goals for transformational change in terms of time, finances, space, quality. Digital ambition allows you to select elements that will be involved in a specific business model of industry. For example, integrating digital and physical worlds into CFS and CHS systems discussed earlier in article. At this stage of transformation, due to digital innovations and technologies, the Internet of Things can emerge, Artificial Intelligence, Neuronet, etc. can be used.

And then, industrial enterprises receive a signal of engagement to set business model priorities at the level of their digital potential.

Digital Potential are the best practices and production drivers that can contribute to digital transformation process of industrial enterprises. And here there are serious questions of system characteristics regarding volatility, uncertainty, complexity, ambiguity of all production and business processes in industrial enterprises. Implementation of Digital Potential is defined as initial stage of a post-transformation business model. In order to mitigate risks of effective realization of digital potential, Analyses process should be implemented in context of following components: Design and Engineering, Production Management, Quality Management, Logistics Management, Design and Engineering: Quote, Concept, Requirements, and Product Planning, Product Design and Engineering, Maintenance Management. For each element of post-transformation business model, different logically integrated options are developed.

It should be noted separately about disruptive power of digital transformation:

1. No need for fixed assets;

2. No need for stocks and storage facilities;

3. No need to create content for network or media;

4. No need for property rights.

Industrial Digital fit \& implementation analyzes design options of post-transformational business model, evaluates and compares it with an existing business model, and finalizes its step-by-step support. Development of design options within digital implementation, budgeting of industrial enterprise resource capabilities is being carried out and a process map of integration innovations at all stages of value chain is being developed.

Reverse stage of transformational change in business models of industrial enterprises is social Digital fit \& implementation, when under influence of new products and services new employment opportunities are created, a social elevator, comfortable living conditions for society, attractiveness of economy for highly qualified personnel increases, and purchasing power increases. Health care, public services and training are becoming available. Such characteristics of transformational change in society at the same time change requirements for industrial production, which affects their business mode.

\section{RESULT AND DISCUSSION}

Digital transformation of industrial enterprise business model and emergence of digital economy is gaining momentum not only in the world, but also in Ukraine, so the topic is becoming more relevant and necessary. Society is justified in innovating information and communication technologies, as they have a two-sided character, both positive and negative. This applies both to specific circumstances and to their implementation in a particular place, and of course economic gains / losses. Given that world's first copy of quantum computer already exists today, and tests are being carried out on others, this revolutionary innovation can affect flow of information and communication events. That is why cyber security of national economy (especially the financial sector) should take lead in Digital Agenda of Ukraine 2020 project, as cyber security is a guarantor in information and communication technologies.

Therefore, modern Ukrainian society and national economy are at new stage of digital development, where information plays a major role. Nowadays, it is impossible to imagine national economy of Ukraine and social activity as a whole, without use of digital technology or information systems and information technologies. Application of modern information technologies at industrial enterprises and transformational changes in their business model allow increasing level of information support of management processes and their effective use. Especially when it comes to economics, business management, government regulation and provision of administrative services and the management of industrial enterprises. The Latest technologies are changing the processes of production and facilitating business process management system, enabling more efficient and better solution of tasks. Therefore, effective management is impossible without detailing elements of conceptual scheme of digital transformation business model of industrial enterprises.

\section{CONCLUSION}

As a result of research, a conceptual scheme of digital transformation business model of industrial enterprises was developed, which details manifestations of emergent 
phenomena in economic system at each stage of implementation. Detailing of components allows adapting activity of industrial enterprises as effectively as possible and provides flexibility reaction of management decisions in trans formative environment. This makes it possible to further predict the most characteristic features of subsystems and their interconnections.

\section{ACKNOWLEDGMENT}

The work was carried out within research work on the subject "Entrepreneurship in the era of global transformations: Challenges and Prospects"' (the state registration number №0119U000718) 2019 years at the University of the State Fiscal Service of Ukraine.

\section{REFERENCES}

1. A Digital report from McKinsey \& Co. [Online]. Available: https://www.mckinsey.com/ru/ /media/McKinsey/Locations/ Europe $\% 20$ and $\% 20$ Middle $\% 20$ East/Russia/Our\%20Insights/Di gital\%20Russia/Digital-Russia-report.ashx Accessed on: Nov. $12,2019$.

2. The future of work in America. People and places, today and tomorrow. July 2019 [Online]. Available: https://www. mckinsey.com/ /media/mckinsey/featured\%20insights/future\% 20of $\% 20$ organizations/the $\% 20$ future $\% 20$ of $\% 20$ work $\% 20$ in $\% 2$ 0america\%20people $\% 20$ and $\% 20$ places $\% 20$ today $\% 20$ and $\% 20 \mathrm{t}$ omorrow/the-future-of-work-in-america-full-report.ashx Accessed on: Nov. 12, 2019.

3. A. Burdina, , T. Nikolenko , L. Semina. "Role of Digital Economy in Creating Innovative Environment", International Journal of Recent Technology and Engineering (IJRTE), vol. 8, is. 3, pp. 6477-6483, 2019. DOI:10.35940/ijrte.C4594.098319. [Online]. Available: https://www.ijrte.org/wp-content/ uploads/papers/v8i3/C4594098319.pdf Accessed on: Nov. 12, 2019.

4. A. Singh, P. Thirumoorthi. "The Impact of Digital Disruption Technologies on Customer Preferences: The Case of Retail Engineering (IJRTE), vo. 8, is 3, pp. 1255-1261, 2019. DOI: 10.35940/ijrte.C4404.098319. [Online]. Available: https://www.ijrte.org/wp-content/uploads/papers/v8i3/C440409 8319.pdf Accessed on: Nov. 12, 2019.

5. Seong-Hoon Lee, Hyun-Soo Jin. "Smart Technology and Industry Trends in Fourth Industrial Revolution", International Journal of Recent Technology and Engineering (IJRTE), vol.8, is 2S6, pp. 400-404, 2019. DOI:10.35940/ijrte.B1075. 0782S619. [Online]. Available: https://www.ijrte.org/wpcontent/uploads/papers/v8i2S6/B10750782S619.pdf Accessed on: Nov. 12, 2019.

6. P. A. Perumal, S. Hammam, C. Tay. "Performance Measure Of Industrial Robotics In Lean Enterprise: A Case Study in Semiconductor Industry", International Journal of Recent Technology and Engineering (IJRTE), vol. 8, Is. 1C5, pp. 12-16, 2019. [Online]. Available: https://www.ijrte.org/wp-content /uploads/papers/v8i1S5/A00030681S519.pdf Accessed on: Nov. 12, 2019.

7. A. Wardaya, Sasmoko, I. Gautama, A. Bandur. "Entrepreneurial Orientation and Digital Technology Capabilities in Small and Medium-sized Enterprises (SMEs) in Indonesia", International Journal of Recent Technology and Engineering (IJRTE), vol. 8, Is. 1C5, pp. 456-460, 2019. [Online]. Available: https://www.ijrte.org/wp-content/uploads/ papers/v8i1C2/A10750581C219.pdf Accessed on: Nov. 12, 2019.

8. M. Sangeetha, S. Arulselvi, S. Saravana, G. Kanagavalli. "IOT Based Industrial Automation", International Journal of Recent Technology and Engineering (IJRTE), vol. 8 is. 1, pp. 29-31, 2019. [Online]. Available: https://www.ijrte.org/wp-content/ Commerce", International Journal of Recent Technology and

uploads/papers/v8i1/A1392058119.pdf Accessed on: Nov. 12 2019.

9. E. Istomina. "Otsenka trendov tsifrovizatsii v promyishlennosti" (Estimation of digitalization trends in industry), Vestnik CHelyabinskogo gosudarstvennogo universiteta (Bulletin of Chelyabinsk State University), vol. 63, no. 12 (422), pp. 108-116, 2018. DOI 10.24411/1994-2796-2018-11212

10. A. Carolis, M. Macchi, E. Negri, S. Terzi. "Guiding manufacturing companies towards digitalization a methodology for supporting manufacturing companies in defining their digitalization roadmap" in 2017 International Conference on Engineering, Technology and Innovation (ICE/ITMC), Funchal, 2017, pp. 487-495. DOI: 10.1109 / ICE.2017.8279925

11. D. Shallmo, C. Williams, L. Boardman. "Digital ttansformation of bussines models - best practice, enablers and roadmap". International Journal of Innovation Management», vol.21, no. 8, pp 1-17, 2017. DOI: 10.1142 / S136391961740014X. [Online]. Available: https://www.worldscientific.com/doi/ pdf/10.1142/S136391961740014XAccessed on: Nov. 12, 2019.

12. M. Voynarenko, Z. Varnalii, V. Hurochkina, O. Menchynska. Estimation of Innovative Business Processes of the Enterprises in Conditions of Emergence Economics. Proceedings of the 6th International Conference on Strategies, Models and Technologies of Economic Systems Management (SMTESM 2019). (Khmelnytskyi, Ukraine, September, 2019). Atlantis Press. Vol. 95. DOI: https://doi.org/10.2991/smtesm19.2019 .32

13. V. V. Shved. Analysis of the practice of using the scientometric platforms in Ukraine. Information Technologies and Learning Tools, 69(1), 235-245. 2019. DOI: https://doi.org/10.33407/ itlt.v69i1.2396

14. M.E. Porter, J.E. Heppelmann, How smart, connected products are transforming competition, Harv. Bus. Rev. 2014. DOI:10.1017/CBO9781107415324.004.

15. Ukraine's Digital Agenda - 2020 Priority areas, initiatives, projects for "digitalization" of Ukraine until 2020. HITECH office. 2016. - 90 p. - [Online]. Available: https://ucci.org.ua/ uploads/files/58e78ee3c3922.pdf. Accessed on: Nov. 10, 2019.

16. On approval of the Concept of development of the digital economy and society of Ukraine for 2018-2020 and approval of the plan of measures for its implementation: document 67-2018. [Online]. Available: http://zakon.rada.gov.ua/laws/show/672018-\%D1\%80

Accessed on: Nov. 10, 2019.

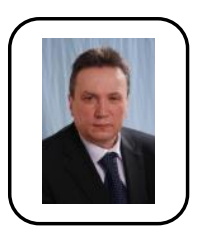

\section{AUTHORS PROFILE}

Volodymyr Bodrov, Doctor of Economics, Professor, Department of Enterprise Economics, University of the State Fiscal Service of Ukraine, Irpin, Ukraine. Honored Scientist of Ukraine, (2004)

Member of European Consultants Unit, Starnberg by Munich (1997). Full Member of the Academy of Economic Sciences of Ukraine (2005)

Author of more than 230 scientific works, including 11 monographs, the main of which are: Social Market Economy (Kyiv, 1995); Transformation of economic systems: concepts, models, mechanisms of regulation and management (Kiev, 2002); State regulation of special monopolies in Ukraine (Kharkiv, 2005); Industrial enterprises of Ukraine in the post-privatization period: mechanisms of state regulation and financial support (Kharkov 2008); State regulation of the economy and economic policy (Kyiv, 2010); Economics of Civilizations in the Global Dimension (Moscow, 2011), State Regulation of the Internal Market Development in the Conditions of Modernization of the National Economy (2013), and others.

$\mathrm{He}$ has delivered scientific presentations and lectures at New York University (USA), University of Munich and Bundeswehr University in Hamburg (Germany), Joint Vienna Institute (Austria), National School of Management (France)

\section{Published By:}

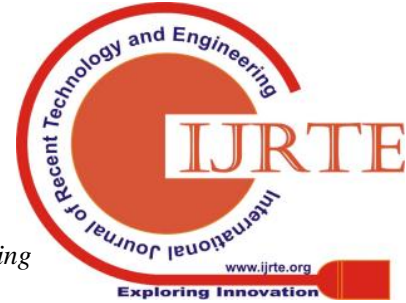


Research field: Governmental regulation of economy and Economic policy analyses, Comparative economic systems, Industrial organization, Digitalization of the economy.

Google Scholar ID: https://scholar.google.com.ua/citations?view_op =list_works\&hl=ru\&user=dx0eS6QAAAAJ

ORCID ID: https://orcid.org/0000-0001-6647-555X

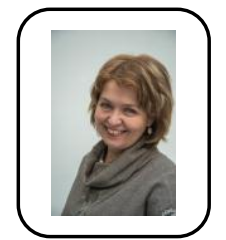

Larisa Lazebnyk, Doctor of Economics, Professor, Department of Enterprise Economics, University of the State Fiscal Service of Ukraine, Irpin, Ukraine.

1990 - graduated from the Faculty of Economics of Kyiv State University. TG Shevchenko, in 1997 postgraduate study of the Department of Economic Theory and Economic Practice of Kyiv State University. TG Shevchenko; in 2007 - doctoral degree at the Ministry of Finance of Ukraine.

Scientific achievements. PhD thesis "Foreign Investment in the Period of Market Transformation of the Ukrainian Economy" (1997), Doctoral dissertation "Financial and Integration Mechanisms for Modernization of the Emergent Economy" (2010). Developed and teaches disciplines: Enterprise Economy, European Integration.

Research field: economic modernization, indicators of enterprise competitiveness. He is the author of over 110 scientific and educational publications

Google Scholar ID: https://scholar.google.com.ua/citations?user= rT1Fh9cAAAAJ\&hl=ru

ORCID ID: https://orcid.org/0000-0003-2234-4093

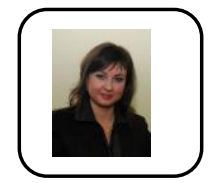

Viktoriya Hurochkina, Phd, Associate Professor Department of Enterprise Economics, University of the State Fiscal Service of Ukraine, Irpin, Ukraine.

The theme of the protected dissertation in 2011: Mechanisms of attraction and use of foreign investments in the enterprises of mechanical engineering. Author of 80 publications, of which 2 are foreign collective monographs (Poland and Great Britain), 4 articles in scientometric bases, 2 articles in foreign editions, 20 articles in professional editions of Ukraine, 32 articles and abstracts in all-Ukrainian and international conferences; co-author of 2 textbooks and 18 educational and methodical publications.

Research field: economic security of the enterprise, value added of the production chain, reengineering, social responsibility, emerging characteristics of economic systems.

Google Scholar ID: https://scholar.google.com.ua/citations?user $=$ SBDc6NkAAAAJ $\& h l=r u$

ORCID ID: https://orcid.org/0000-0001-8869-0189

ResearchGate:

https://www.researchgate.net/profile/Viktoriya_Hurochkina

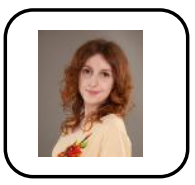

Ruslana Lisova, Postgraduate Student, University of the State Fiscal Service of Ukraine, Irpin, Ukraine.

Research topic: Transformation of business models in the conditions of formation of digital economy in Ukraine. Twelve papers were published on the topic of the research, of which 2 articles were in scientific-metric bases, 2 articles in professional editions of Ukraine, 8 abstracts in all-Ukrainian and international conferences. The influence of digitalization of economy on the business model of companies, the use of progressive in production and methods of determining the digital maturity of the enterprise are investigated in the works.

Research field: digitalization of economy, digital transformation of business models, introduction of advanced technologies into production, digital entrepreneurship, platform business models and digital competencies.

Google Scholar ID: https://scholar.google.com.ua/citations?

$\mathrm{hl}=\mathrm{uk} \&$ user=LBd2VbIAAAAJ

ORCID ID: https://orcid.org/0000-0001-7999-1078

LinkedIn: https://www.linkedin.com/in/ruslana-lisova 